\title{
LARVAL AND PUPAL STAGE OF Spodoptera frugiperda (J. E. Smith) (LEPIDOPTERA: NOCTUIDAE) IN SWEET AND FIELD CORN GENOTYPES
}

\author{
SANTOS, L. M., REDAELLI, L. R., DIEFENBACH, L. M. G. and EFROM, C. F. S. \\ ${ }^{1}$ Departamento de Fitossanidade, Faculdade de Agronomia UFRGS, Av. Bento Gonçalves, 7712, \\ CEP 91540-000, Porto Alegre, RS, Brazil \\ Correspondence to: Luiza Rodrigues Redaelli, Rua Engenheiro Afonso Cavalcanti, 31/1002, \\ CEP 90440-110, Porto Alegre, RS, Brazil, e-mail: luredael@ vortex.ufrgs.br \\ Received May 17, 2002 - Accepted August 29, 2002 - Distributed November 30, 2003
}

(With 1 figure)

\begin{abstract}
Spodoptera frugiperda, the fall armyworm, is a very significant polyphagous pest due to the damages it causes, and control difficulties. Lack of information about its impact on sweet corn motivated a comparison of its biology, with respect to the larval and pupal stages, among the genotypes ELISA, BR 400 (sweet corns), and BR PAMPA (field corn). In laboratory conditions $\left(25 \pm 1^{\circ} \mathrm{C} ; 70 \pm 10 \% \mathrm{RH}\right.$; photophase 12 hours), 35 caterpillars were individualized and fed daily with $3.14 \mathrm{~cm}^{2}$ sections of corn leaves from the referred-to genotypes, cultivated in plots in the experimental area of the Departament of Fitossanidade, UFRGS, Porto Alegre, RS from October to November 2000. The caterpillars were weighed daily; after each molt, the cephalic capsules were collected and measured (in width), to establish growth rate; pupae were weighed and sexed when 24 hours old. The duration of the larval instars, the pupal sex ratio, and the mortality of larvae and pupae were evaluated. In the first three instars there were no differences registered in capsule width. In the fourth and fifth instars, capsules of caterpillars kept in BR 400 were smaller. The weight of caterpillars and pupae, instar duration and sex ratio did not differ among the genotypes. Pupal phase duration was less in females kept in BR 400. Mortality was greater in the larval phase in ELISA and in the pupal phase in BR PAMPA.
\end{abstract}

Key words: Spodoptera frugiperda, fall armyworm, sweet corn.

\section{RESUMO}

\section{Fases larval e pupal de Spodoptera frugiperda (J. E. Smith) (Lepidoptera: Noctuidae)} em genótipos de milho doce e comum

Spodoptera frugiperda, a lagarta-do-cartucho-do-milho, é uma praga polífaga de grande importância agrícola pelos danos e dificuldade de controle. A ausência de informações sobre seu impacto em milho doce motivou a comparação de sua biologia, no que tange as fases larval e pupal, entre os genótipos de milho ELISA, BR 400 (milhos doces) e BR PAMPA (milho comum). Em condições de laboratório $\left(25 \pm 1^{\circ} \mathrm{C} ; 70 \pm 10 \%\right.$ UR; fotofase 12 horas), 35 lagartas foram individualizadas e alimentadas, diariamente, com seções de folhas de $3,14 \mathrm{~cm}^{2}$ dos referidos genótipos, provenientes de parcelas estabelecidas na área experimental do Departamento de Fitossanidade, UFRGS, Porto Alegre, RS, de outubro a novembro de 2000. As lagartas foram pesadas diariamente e após cada ecdise as cápsulas cefálicas eram recolhidas e mensuradas quanto à largura, para estabelecer a razão de crescimento. As pupas foram pesadas e sexadas com 24 horas de idade. Avaliaram-se a duração dos ínstares larvais, a razão sexual das pupas e a mortalidade larval e pupal. Não se registrou diferença na largura das cápsulas nos três primeiros ínstares. No quarto e quinto ínstares, as cápsulas das lagartas mantidas em BR 400 foram menores. O peso das lagartas e das pupas, a duração dos ínstares e a razão sexual não diferiram entre os genótipos. A duração da fase pupal foi menor nas fêmeas mantidas em BR 400. A mortalidade foi maior, na fase larval, em ELISA e, na pupal, em BR PAMPA.

Palavras-chave: Spodoptera frugiperda, lagarta-do-cartucho-do-milho, milho doce. 


\section{INTRODUCTION}

Spodoptera frugiperda (J.E. Smith, 1797) (Lepidoptera: Noctuidae), the fall armyworm, is a polyphagous pest of enormous agricultural importance, not only because of the damage it provokes, but also because of control difficulties (Leiderman \& Sauer, 1953; Cruz \& Turpin, 1983; Gassen, 1996). In the corn culture, attack may occur from the seedling phase until tasselling and earing. The small caterpillars begin scraping the foliar limb of younger leaves, and then damage the central leaves of the midwhorl, which can be totally destroyed. In late occurrences, the caterpillars may attack the ear, destroying straw and grains; furthermore, they may facilitate entry of humidity and pathogens, causing rot (Ávila et al., 1997). In sweet corn genotypes, besides this damage, a commercial decrease in value occurs, since the final product is consumed as is.

The physiology, behavior, ecology, and evolution of insect species are greatly affected by nutritional factors. Consumed food quantity and quality during the larval phase affect the growing rate, development time, body weight, and survival, as well as influencing adult fecundity and longevity (Scriber \& Slansky-Jr., 1981). The insects respond to food quality variation with adaptations, allowing them to compensate for the effects thus caused (Slansky-Jr. \& Scriber, 1985). The young forms (larvae and nymphae) tend to choose certain foods which they consume in balanced proportions, leading to optimized growth and development. The choice involves adaptations and strategies, including the compensatory capacity, on the part of each species. (Parra, 1991). Crocomo \& Parra (1985) have already pointed out these aspects in analyzing the behavior of $S$. frugiperda caterpillars fed with corn, wheat, and sorghum leaves; it was verified that these caterpillars have a compensatory capacity throughout the larval period, the three vegetal species resulting in a similar compensation.

It is possible to determine the effect that different vegetal species and/or genotypes of the same species can have on phytophagous insects by accompanying and evaluating elements of the life cycle such as duration, weight, mortality, and growth rate. Those measurements so determined are useful in selecting sources of resistance.

Relative to the biology of this species, diverse studies have been developed, especially on corn culture (Kasten-Jr. et al., 1978; Melo, 1984; Vendramim \& Fancelli, 1988; Garcia \& Clavijo,
1989; Silveira et al., 1997). However, relative to sweet corn culture, studies of this nature do not exist in Brazil.

Thus, this work aimed to evaluate the development of pupal and larval stage of S. frugiperda in ELISA and BR 400 (sweet corns), and in BR PAMPA (field corn) genotypes.

\section{MATERIAL AND METHODS}

The experiment was carried out in the Laboratório de Biologia e Ecologia de Insetos and in the experimental area of the Departamento de Fitossanidade, Universidade Federal do Rio Grande do Sul, Porto Alegre ( $30^{\circ} 01^{\prime} \mathrm{S}$ and $\left.50^{\circ} 13^{\prime} \mathrm{W}\right)$, RS, during November and December 2000. Plots of three corn genotypes, ELISA and BR 400 (sweet corns) and BR PAMPA (field corn) were cultivated, following the habitual recommendations in relation to fertilization and cultivaton practices.

In the laboratory $\left(25 \pm 1^{\circ} \mathrm{C} ; 70 \pm 10 \% \mathrm{RH}\right.$; photophase 12 hours), newly emerged caterpillars obtained from eggs from a mass rearing (AVENTIS, Paulínia, SP) were individualized and kept in transparent plastic boxes $(11 \mathrm{~cm} \times 11 \mathrm{~cm} \times 3.5 \mathrm{~cm})$ during the entire larval and pupal phases. The caterpillars were fed daily, ad libidum, with $3.14 \mathrm{~cm}^{2}$ circular sections of leaves from plants 25 to 40 dayold plants from the genotypes previously referred to. The leaves were previously emersed in a $1 \%$ sodium hypochlorite solution for approximately three minutes and then washed in distilled water. Thirtyfive individuals/genotype were used. Until the third instar, the daily procedures were food exchange, recipient cleanings, record of deaths, and collection of cephalic capsules. From the third instar on, each caterpillar was weighed daily with a precision scale with an approximation of $0.001 \mathrm{~g}$.

Evaluation of the duration and number of instars was possible through the daily observations, as well as cephalic capsules collected, and individualized in ependorf flasks until measured:

To establish the growth rate, measurement of cephalic capsule width was done with the aid of a micrometric ocular connected to a Wild M5 stereomicroscope.

The pupae obtained were sexed through the Butt \& Cantu (1962) technique and weigh when 24hours-old, when the sex ratio was also determined. Duration and viability of this period were also evaluated. 
The data were submitted to variance analysis and the averages compared by Tukey test through SAS software. Data related to mortality and sex ratio were analyzed through the $\chi^{2}$ at $5 \%$ significance level. Data referring to the growth rate (cephalic capsule width) were analyzed through linear regression at 5\% significance level.

\section{RESULTS AND DISCUSSION}

In all genotypes, the caterpillars had five to seven larval instars, with the majority, in all genotypes, having six. The average cephalic capsule width did not differ significantly in first, second, and third instars in caterpillars fed with circular sections of leaves from ELISA, BR 400, and BR PAMPA genotypes $(\mathrm{P}=0.71)$, $(\mathrm{P}=0.38)$, and $(\mathrm{P}=0.85)$, respectively. However, in the fourth and fifth instars, the cephalic capsules of the caterpillars kept on BR 400 genotype were smaller by a significant difference than the ones kept on the other genotypes $(\mathrm{P}=0.02)$ (Table 1$)$. The growth rate for all instars, considering the evaluated genotypes, followed a geometric progression, verified through the regression analysis; the average values were very close to those related by Dyar (1890) for other lepidoptera (Table 1). The results for average cephalic capsule width in this study are similar to those observed by Bailey \& Chada (1968) for $S$. frugiperda, fed with sorghum grain, in five instars: $0.27,0.45,0.85,1.44$, and 2.15 , respectively. These results are also similar to those found by Machado et al. (1985) working with S. frugiperda fed with kale. The authors registered for first, second, third, fourth, fifth, and sixth instars average values of $0.28,0.47,0.80,1.29,1.91$, and $2.82 \mathrm{~mm}$, respectively; growth rate was also similar. However, Rezende et al. (1994) recorded values similar to those of this study for $S$. frugiperda fed on corn leaves, but only for the first and second instars; for the others, the average values were lesser.

Comparing the average duration of each instar between the genotypes, no significant difference was verified (first instar, $\mathrm{P}=0.59$; second instar, $\mathrm{P}=0.98$; third instar, $\mathrm{P}=0.35$; fourth ins$\operatorname{tar}, \mathrm{P}=0.72$; and fifth instar, $\mathrm{P}=0.17$ ). Nevertheless, it was observed that the first instar was longer in relation to the others, followed by the fifth; the duration of the third was shorter in all considered genotypes (Table 2). Garcia \& Clavijo (1989) mention the same tendency, with values of 3.94, 2.22, $2.10,2.16$, and 2.51 days, for the same species, having different food sources, and for the first, second, third, fourth, and fifth instars, respectively.

TABLE 1

Average width of cephalic capsules $(\mathrm{mm})( \pm \mathrm{SE})$ and growth rate of larval instars of Spodoptera frugiperda in laboratory conditions $\left(25 \pm 1^{\circ} \mathrm{C} ; 70 \pm 10 \% \mathrm{RH}\right.$; photophase 12 hours $)$, Porto Alegre, RS, 2000.

\begin{tabular}{|c|c|c|c|c|c|c|}
\hline \multirow{3}{*}{ Instar } & \multicolumn{2}{|c|}{ ELISA } & \multicolumn{2}{c|}{ BR 400 } & \multicolumn{2}{c|}{ BR PAMPA } \\
\cline { 2 - 7 } & Width & RC & Width & RC & Width & RC \\
\hline \multirow{2}{*}{ I } & $0.32 \pm 0.003$ & & $0.32 \pm 0.004$ & & $0.31 \pm 0.003$ & \\
\cline { 2 - 7 } & & 1.535 & & 1.551 & & 1.491 \\
\hline \multirow{2}{*}{ II } & $0.50 \pm 0.004$ & & $0.49 \pm 0.007$ & & $0.47 \pm 0.004$ & \\
\cline { 2 - 7 } & & 1.680 & & 1.667 & & 1,800 \\
\hline \multirow{2}{*}{ III } & $0.83 \pm 0.006$ & & $0.82 \pm 0.011$ & & $0.84 \pm 0.006$ & \\
\cline { 2 - 7 } & & 1.704 & & 1.520 & & 1.613 \\
\hline \multirow{2}{*}{ IV } & $1.42 \pm 0.006 \mathrm{a}^{1}$ & & $1.24 \pm 0.015 \mathrm{~b}$ & & $1.36 \pm 0.006 \mathrm{a}$ & \\
\cline { 2 - 7 } & & 1.481 & & 1.484 & & 1.487 \\
\hline V & $2.10 \pm 0.008 \mathrm{a}$ & & $1.84 \pm 0.012 \mathrm{~b}$ & & $2.02 \pm 0.007 \mathrm{a}$ & \\
\hline
\end{tabular}

${ }^{1}$ Averages followed by the same letter in the line do not differ statistically by the Tukey test at $5 \%$. 
The average caterpillar weight in the third, fourth, and fifth instars presented no significant difference between the considered genotypes $(\mathrm{P}=$ $0.12, P=0.16$, and $P=0.17$ ), respectively (Table 3). Melo (1984), working with the same species, kept on AG 28 genotype, found in the fourth and fifth instars values less than those of the present study: 0.64 and $0.13 \mathrm{~g}$, respectively. For these same instars, higher values were registered for P 6872 and AG 64: 0.187 and 0.568, and 0.262 and $0.790 \mathrm{~g}$, respectively. The differences in values found could be attributed, among other factors, to the diverse environmental conditions in which the insects were kept, physical and chemical characteristics intrinsic to each genotype, and insect origins.

Regarding the average weight of pupae, no significant difference was observed between the evaluated genotypes for either males or females $(\mathrm{P}=$ $0.20)$ and $(\mathrm{P}=0.70)$ respectively (Table 4$)$. Melo (1984) registered for the weight of male pupae from caterpillars kept in AG 64 and P 6872 corn genotypes values similar to those of this study in BR 400 and BR PAMPA genotypes, respectively. The same author registered similar values for the weight of female pupae from caterpillars kept on AG 64 corn genotype, in relation to BR 400 genotype. The values presented here are less than those found by Kasten-Jr. et al. (1978) for S. frugiperda, in corn culture under laboratory conditions $\left(25 \pm 1^{\circ} \mathrm{C} ; 70 \pm 10 \% \mathrm{RH}\right.$; photophase 12 hours), for both males and females: 0.228 and $0.245 \mathrm{~g}$, respectively. Higher average values were registered by Silveira et al. (1997) for $S$. frugiperda, in 11 corn genotypes under laboratory conditions $\left(25 \pm 1^{\circ} \mathrm{C} ; 70 \pm\right.$ $10 \% \mathrm{RH}$; photophase 12 hours), when weight of both males and females was considered. Vendramim \& Fancelli (1988) also found high average values for the same species in six corn genotypes when weights of pupae of both sexes together were compared. The differences found in these studies could be attributed mainly to the environmental conditions in which the insects were kept, as well as to the inherent genotype characteristics and the insect origin.

Concerning average duration of the pupal period, it was observed to be shorter in females from caterpillars kept on $\mathrm{BR} 400(\mathrm{P}=0.04)$ while no significant difference was observed in males $(\mathrm{P}=0.22)$. (Table 4). Kasten-Jr. et al. (1978), considering average duration of the pupal phase, independent of sex, found a lesser value (7.96 days). The higher duration registered in the present study could be attributed to maintaining the insects at a lower temperature than that used by the latter author $\left(27 \pm 2^{\circ} \mathrm{C}\right)$. Garcia \& Clavijo (1989), working at $25^{\circ} \mathrm{C}$ and $80 \% \mathrm{RH}$, found values similar to those presented in this study for both males (9.5 days) and females (8.5 days), from caterpillars fed on plants of up to 45-days-old.

The obtained sexual ratio was $0.63,0.50$, and 0.53 in ELISA, BR 400, and BR PAMPA genotypes, respectively; the difference among the genotypes was not significant. Silveira et al. (1997), working with various genotypes, found an average value of 0.50 , similar to that found in the present study.

TABLE 2

Average duration of the different instars (days) $( \pm \mathrm{SE})$ of Spodoptera frugiperda under laboratory conditions $(25 \pm$ $1^{\circ} \mathrm{C} ; 70 \pm 10 \% \mathrm{RH}$; photophase 12 hours), in three corn genotypes. Porto Alegre, RS, 2000.

\begin{tabular}{|c|c|c|c|}
\hline Instar & ELISA & BR 400 & BR PAMPA \\
\hline I & $3.04 \pm 0.144$ & $2.97 \pm 0.145$ & $3.12 \pm 0.056^{*}$ \\
\hline II & $1.89 \pm 0.109$ & $1.90 \pm 0.117$ & $1.88 \pm 0.095$ \\
\hline III & $1.70 \pm 0.135$ & $1.78 \pm 0.140$ & $1.51 \pm 0.138$ \\
\hline IV & $2.07 \pm 0.178$ & $1.97 \pm 0.138$ & $2.12 \pm 0.133$ \\
\hline V & $2.27 \pm 0.209$ & $2.56 \pm 0.220$ & $3.00 \pm 0.359$ \\
\hline
\end{tabular}

*Not significant by the $\mathrm{F}$ test at $5 \%$. 
TABLE 3

Average weight (g) ( \pm SE) of Spodoptera frugiperda caterpillars kept in three corn genotypes, in laboratory conditions $\left(25 \pm 1^{\circ} \mathrm{C} ; 70 \pm 10 \%\right.$ RH; photophase 12 hours $)$. Porto Alegre, RS, 2000.

\begin{tabular}{|l|c|c|c|}
\hline \multirow{2}{*}{ Genotype } & \multicolumn{3}{|c|}{ Instar } \\
\cline { 2 - 4 } & III & IV & V \\
\hline ELISA & $0.04 \pm 0.003$ & $0.15 \pm 0.009$ & $0.35 \pm 0.009^{*}$ \\
\hline BR 400 & $0.04 \pm 0.004$ & $0.12 \pm 0.013$ & $0.32 \pm 0.016$ \\
\hline BR PAMPA & $0.03 \pm 0.002$ & $0.13 \pm 0.009$ & $0.32 \pm 0.007$ \\
\hline
\end{tabular}

*Not significant by the $\mathrm{F}$ test at $5 \%$.

TABLE 4

Average weight (g) ( \pm SE) of pupae (24 hours) and average duration (days) of the pupal stage of Spodoptera frugiperda males and females, originated from caterpillars kept in three corn genotypes, in laboratory conditions $\left(25 \pm 1^{\circ} \mathrm{C} ; 70 \pm 10 \% \mathrm{RH}\right.$; photophase 12 hours $)$. Porto Alegre, RS, 2000.

\begin{tabular}{|l|c|c|c|c|}
\hline \multirow{2}{*}{ Genotype } & \multicolumn{2}{c|}{ Weight } & \multicolumn{2}{c|}{ Duration } \\
\cline { 2 - 5 } & Males & Females & Males & Females \\
\hline ELISA & $0.20 \pm 0.008$ & $0.18 \pm 0.005^{1}$ & $9.79 \pm 0.261$ & $9.44 \pm 0.294 \mathrm{a}^{1}$ \\
\hline BR 400 & $0.19 \pm 0.012$ & $0.17 \pm 0.013$ & $10.86 \pm 1.079$ & $8.50 \pm 0.224 \mathrm{~b}$ \\
\hline BR PAMPA & $0.17 \pm 0.018$ & $0.18 \pm 0.006$ & $10.61 \pm 0.241$ & $9.17 \pm 0.167 \mathrm{a}$ \\
\hline
\end{tabular}

${ }^{1}$ Averages followed by same letter in the column do not differ statistically by the Tukey test at $5 \%$.

For the larval stage, no difference was registered in relation to the mortality of individuals kept on ELISA, BR 400, and BR PAMPA: 22.86, 14.28, and $14.28 \%$, respectively $\left(\chi^{2}=1.00 ; \mathrm{gl}=2 ; \alpha=0.05\right)$. Kasten- Jr et al. (1978), Melo (1984), and Vendramin $\&$ Fancelli (1988) registered mortality of $13.7 \%$, $13.2 \%$, and $14 \%$, respectively, values similar to those found in BR400 and BR PAMPA. However, in considering cultivates P 6872 e AG 64, Melo (1984) did not register mortality. In the pupal stage no difference was observed among the individuals kept on ELISA, BR 400, and BR PAMPA genotypes: $14.81,13.33$, and 16.61 , respectively $\left(\chi^{2}=0.141\right.$; $\mathrm{gl}=2 ; \alpha=0.05)$. These data are superior to those found by Kasten- Jr. et al. (1978), Melo (1984), and Vendramim \& Fancelli (1988): 8.70, 8.63, and 8.90\%, respectively. Garcia \& Clavijo (1989) observed a greater mortality (22\%) for pupae from caterpillars fed on corn plants no more than 45-days-old.

In BR 400, lower values were found for cephalic capsule width of fourth and fifth instars caterpillars. Those values indicate smaller-size individuals from which could originate smaller pupae and adults with potentially lesser reproductive capacity and/or lesser longevity, resulting in smaller population size and, consequently, lower damage potential. However, no difference was verified among the genotypes in relation to: average duration of different larval instars, caterpillar and pupae weights, average duration of pupal stage in males, and sex ratio. The female pupae originating from caterpillars kept in BR 400, were similar in weight to other genotypes but presented the shortest duration of this stage. 
Considering ELISA and BR PAMPA genotypes, higher values for the average cephalic capsule width were registered, which indicates larger size of the individuals and could mean larger pupae and adults with higher reproductive capacity. On the other hand, the pupal stage of females from caterpillars fed on these genotypes was longer. Nevertheless, it should be emphasized that the longer duration of pupal stage in these genotypes may result in a smaller number of generations within a cultivation cycle.

The results obtained demonstrate that under laboratory conditions the three evaluated genotypes did not present, among them, differential effects in S. frugiperda larval and pupal stage, and showed no evidence of antibiosis.

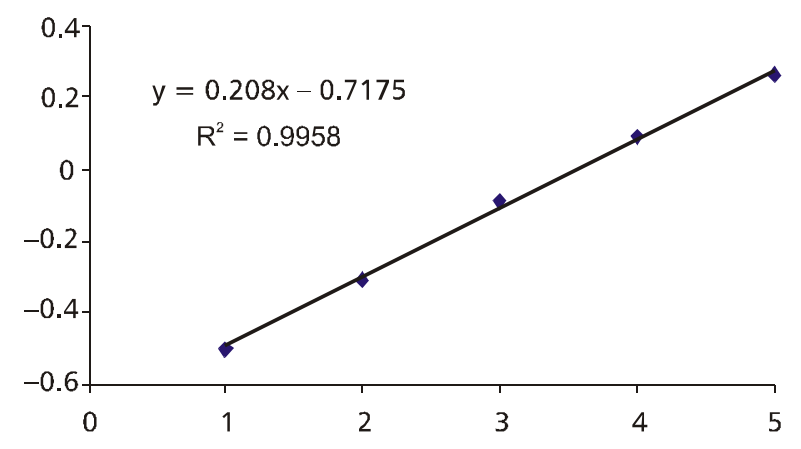

A

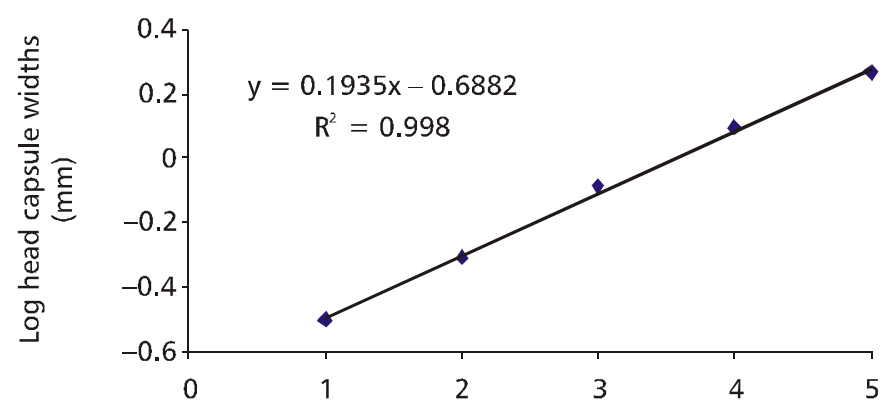

B

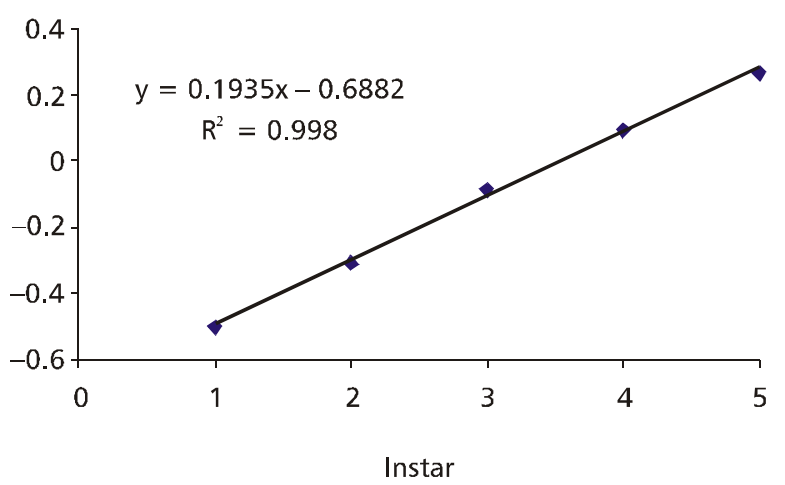

Fig. 1 - Regression between average cephalic capsules width and larval instars of Spodoptera frugiperda, in ELISA (A), BR 400 (B), and BR PAMPA (C), in laboratory conditions $\left(25 \pm 1^{\circ} \mathrm{C}\right.$; $70 \pm 10 \% \mathrm{RH}$; photophase 12 hours), Porto Alegre, RS, 2000. 


\section{REFERENCES}

ÁVILA, C. J., DE GRANDE, P. E. \& GOMEZ, S. A., 1997, Insetos-pragas: reconhecimento, comportamento, danos e controle, pp. 168-180. In: Milho: informações técnicas. EMBRAPA, Circular Técnica, 5, Dourados.

BAILEY, D. L. \& CHADA, H. L., 1968, Effects of natural (sorghum) and artificial (wheatgerm) diets on development of the corn earworm, fall armyworm, and southwestern corn borer. J. Econ. Entomol., 1: 257-260.

BUTT, B. A. \& CANTU, E., 1962, Sex determination of lepidopterous pupae. UDSA-ARS, pp. 33-75.

CROCOMO, W. B. \& PARRA, J. P., 1985, Consumo e utilização de milho, trigo e sorgo por Spodoptera frugiperda (J. E. Smith, 1797) (Lepidoptera: Noctuidae). Rev. Bras. Entomol., 1: $225-260$.

CRUZ, I. \& TURPIN, F. T., 1983, Yield impact of larval infestations of the fall armyworm (Lepidoptera: Noctuidae) to midwhorl growth stage of corn. J. Econ. Entomol., 5: 1052-1054.

DYAR, H. G., 1890, The number of molts in lepidopterous larvae. Psyche, 5: 420-422.

GARCIA, J. L. \& CLAVIJO, S. A., 1989, Efecto de la alimentación sobre la duración y sobrevivencia de las fases de larva, prepupa y pupa de Spodoptera frugiperda (Smith). Bol. Entomol. Venez. N. S., 5: 28-36.

GASSEN, D. N., 1996, Manejo de pragas associadas à cultura milho: pragas da parte aérea das plantas. Aldeia Norte, Passo Fundo, 136p.

KASTEN-Jr., P., PRECETTI, A. A. C. M. \& PARRA, R. P., 1978, Dados biológicos comparativos de Spodoptera frugiperda (J. E. Smith, 1797) em duas dietas artificiais e substrato natural. Rev. Agric., 53: 69-78.

LEIDERMAN, L. M. \& SAUER, H. F. G., 1953, A lagarta dos milharais. $O$ Biol., 6: 105-113.
MACHADO, V. L. L., GIANOTTI, E. \& OLIVEIRA, R. M., 1985, Aspectos biológicos de Spodoptera frugiperda (J. E. Smith, 1797) (Lepidoptera: Noctuidae) em couve (Brassica oleracea L. var. acephala). An. Soc. Ent.. Bras., 1: 121-130.

MELO, M., 1984, Aspectos biológicos e consumo foliar de Spodoptera frugiperda (J. E. Smith, 1797) (Lepidoptera: Noctuidae) em três cultivares de milho. Dissertação de Mestrado em Fitotecnia, Faculdade de Agronomia, UFRGS, Porto Alegre, 71p.

PARRA, J. R. P., 1991, Consumo e utilização de alimentos por insetos, pp. 9-65. In: A. R. Panizzi \& J. R. P. Parra (eds.), Ecologia nutricional de insetos e suas implicações no manejo de pragas. Manole, São Paulo, 390p.

REZENDE, M. A. A., CRUZ, I. \& DELLA LUCIA, T. M. C., 1994, Consumo foliar de milho e desenvolvimento de lagartas de Spodoptera frugiperda (Smith) parasitadas por Chelonus insularis (Cresson) (Hymenoptera: Braconidae). An. Soc. Ent. Bras., 3: 473-478.

SCRIBER, J. M. \& SLANSKY-Jr., F., 1981, The nutritional ecology of immature insects. Ann. Rev. Entomol., 26: 183211

SILVEIRA, L. C. P., VENDRAMIM, J. D. \& ROSSETO, C. J., 1997, Efeito de genótipos e milho no desenvolvimento de Spodoptera frugiperda (J. E. Smith, 1797). An. Soc. Ent. Bras., 2: 291-298.

SLANSKY-Jr. F. \& SCRIBER, J. M., 1985, Food consumption and utilization. In: G. A. Kerkut \& L. I. Gilbert (eds.), Comprehensive insect physiology, biochemistry and pharmacology. Pergamon Press, Oxford, vol. 3, pp. 87-163.

VENDRAMIM, J. D. \& FANCELLI, M., 1988, Efeito de genótipos de milho na biologia de Spodoptera frugiperda (J. E. Smith, 1797) (Lepidoptera: Noctuidae). An. Soc. Ent. Bras., 17 (supl.). 